\title{
ELECTRON MOBILITY DEPENDENCE ON NEUTRON IRRADIATION FLUENCE IN HEAVILY IRRADIATED SILICON
}

\author{
J.V. Vaitkus, A. Mekys, and Š. Vaitekonis \\ Institute of Photonics and Nanotechnology, Vilnius University, Sauletekio 3, 10257 Vilnius, Lithuania \\ Email: juozas.vaitkus@ff.vu.lt
}

Received 12 May 2021; accepted 13 May 2021

\begin{abstract}
An increase of neutron irradiation fluence caused a decrease of Si radiation detector efficiency that was exceptionally well seen at $10^{17}$ neutron $/ \mathrm{cm}^{2}$ fluence when the observed $I-V$ characteristic of p-n junction under forward bias and under reverse bias became similar. Therefore the investigation of free carrier mobility could be a key experiment to understand the change of heavily irradiated silicon.

The electron mobility was investigated by magnetoresistance means in microstrip silicon samples at temperature range $T=200-276 \mathrm{~K}$. The analysis included the free carrier scattering by phonons, ionized impurities, dipoles and clusters and a contribution of each process was found by fitting the mobility dependence on temperature.

The analysis of experimental data clearly demonstrated that the applied model did not explain the mobility in the samples irradiated to the highest fluence. Therefore a new concept of carrier transport is needed, and, as a conclusion, it could be stated that $\mathrm{Si}$ irradiated above $10^{16} \mathrm{~cm}^{-2}$ fluence (and up to $10^{20} \mathrm{~cm}^{-2}$ ) is a disordered material with the clusters.
\end{abstract}

Keywords: irradiation detector, silicon, mobility

PACS: $61.80 . \mathrm{Lj}, 72.20 . \mathrm{Fr}, 77.55 . \mathrm{df}$

\section{Introduction}

Silicon semiconductor detectors widely used in lowand high-energy physics, medicine and environmental applications are quite sensitive to radiation damage. Passage of an ionizing particle through a base material may cause defects of the crystal lattice: displacements (vacancies and interstitial Si atoms) and clusters, similar to tens-mm-size disordered structure inclusions due to knockouts of atoms from lattice sites [1]. The vacancies and interstitials lead to the formation of new trapping and recombination of carriers centres, as well as to a change in their effective (donor and acceptor) concentration, and could cause a transform of the oxygen clusters that are different in magnetic Czochralski (MCZ) and floating-zone (FZ) silicon [2, 3]. These processes at high irradiation doses significantly deteriorate the energy resolution of the radiation detectors and reduce their signal amplitude, that can be attributed to a decrease in the carrier lifetime and mobility, and can cause incomplete charge collection.

It was demonstrated [4] that the detector current under forward bias is larger than under reverse bias at the same voltage but the difference becomes smaller at higher fluence, and at $10^{17}$ neutron $/ \mathrm{cm}^{2}$ fluence the current equalizes. This result confirms the change in free carrier transport properties, and the investigation of mobility could be a key experiment to understand the change of properties in heavily irradiated silicon.

Main defects introduced by the high energy neutrons are clusters [1], the concentration of which is proportional to fluence. They are the main recombination centres in Si irradiated with neutrons, protons and pions [5], also this shows that the contribution of point defects is very small in Si irradiated by neutrons. As the free carrier reciprocal lifetime 
linearly increases if the hadron fluence increases at least over six orders of magnitude, it shows the existence of recombination centres that rapidly capture electrons and holes. It was proposed [6, 6] that the clusters could have the dipole properties which could also influence free carrier mobility. This was supported by imitating the damage created by a highenergy particle (HEP) after collision. Dipole structure HEP caused damage was obtained from simulations with the crystal TRIM (Transport of Ions In Matter) software [8], and it was shown that vacancy and interstitial enriched regions are spatially separated [9]. It was observed in agreement [10] with expectations that there was no change (within $5-10 \%$ errors) in mobility or saturation velocity for both electrons and holes in Si irradiated to $10^{14} \mathrm{~cm}^{-2}$ fluence. The indications were found that in more heavily irradiated diodes the space charge density is nonuniform, and this excluded possibility to exploit the Hall effect to measure the mobility of carriers in more heavily irradiated Si. The investigation of Si samples irradiated to the similar and higher fluence confirmed this statement and demonstrated possibility to measure the mobility of carriers by magnetoresistivity effect that is less dependent on sample inhomogeneity than the Hall effect [11]. There a decrease of electron mobility was observed in Si irradiated to higher neutron fluence. In this work, the research has followed the same methodology to analyse the data in Si irradiated to extreme high fluence.

\section{Experimental details}

Two sets of microstrip silicon samples ( $43 \mu \mathrm{m}$ width between strips, $10 \mathrm{~mm}$ length and $0.375 \mathrm{~mm}$ thickness) having an electron (phosphorus-doped) conductivity type were used in our experiments. More technical details may be found in our previous work [11] since this is the extension of investigation of the Si samples irradiated to higher neutron fluence. Magnetoresistance mobility $\mu_{\mathrm{M}}$ in homogeneous crystals is related to the data obtained from the magnetoresistance effect measurements by the following relation [12]:

$$
\mu_{\mathrm{M}}=B^{-1}\left(\rho_{B} / \rho_{0}-1\right)^{1 / 2}=B^{-1}\left(I_{0} / I_{B}-1\right)^{1 / 2} .
$$

Here $B$ is the applied magnetic induction, $\rho_{0}$ and $\rho_{B}$ are the resistivity, and $I_{0}$ and $I_{B}$ are the electric current with the magnetic field absent (0) and ap- plied $(B)$, respectively. The quadratic dependence of the magnetoresistance with magnetic induction was observed (Fig. 1).

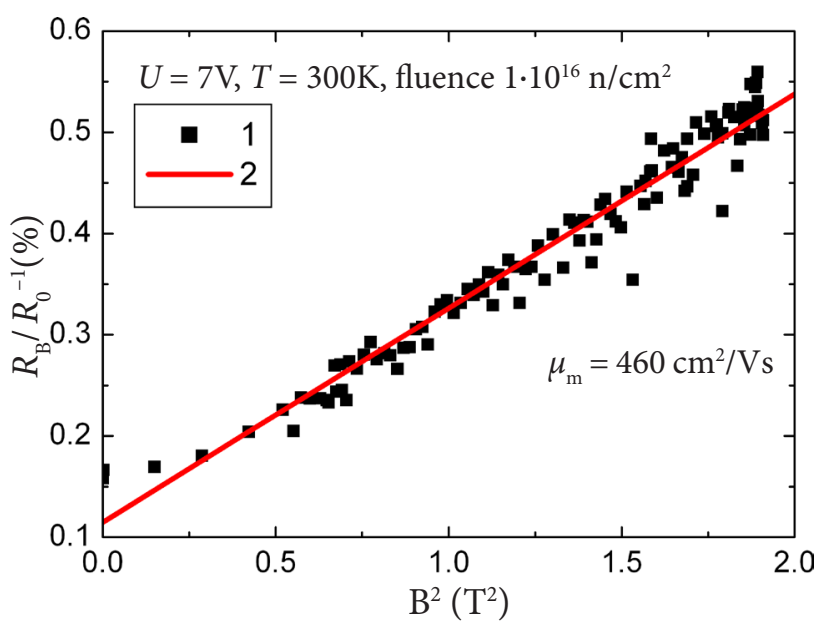

Fig. 1. The magnetoresistance dependence on squared magnetic induction. Squares represent experiment, a solid line (red online) shows linear fit. Magnetoresistant mobility is calculated from the slope of the fit.

Also, the relation of free carrier drift and magnetoresistance mobility given in [13] was taken into account: the factor for low magnetic field in bulk silicon irradiated to high fluence, i.e. Coulomb scattering, is equal to 2.43 . Therefore the fitting of electron mobility data was performed by the relation according to the Matthiessen's rule

$$
\begin{aligned}
& \mu=\left(1 / \mu_{\text {phon }}+1 / \mu_{\text {ionized }}+1 / \mu_{\text {clusters }}+1 / \mu_{\text {dipoles }}\right)^{-1} \\
& =\left(1 / a T^{-2.42}+1 / b T^{1.5}+1 / c T^{-1}+1 / d T^{-0.5}\right)^{-1}
\end{aligned}
$$

and here $\mu_{\text {hon }}$ means the mobility of electrons in the undoped sample. The electron mobility limited by ionized impurity scattering was evaluated by the Conwell-Weisskopf formula [14]

$$
\begin{aligned}
& \mu=\left(\frac{3.68 \cdot 10^{20}}{N_{\mathrm{i}}}\right) \cdot \frac{1}{Z^{2}} \cdot\left(\frac{e}{11.9}\right)^{2} \cdot\left(\frac{T}{100}\right)^{3 / 2} \\
& \cdot\left(\frac{m_{0}}{m}\right)^{1 / 2} \cdot \frac{1}{\lg \left(1+b^{2}\right)},
\end{aligned}
$$

where

$$
b=\frac{e}{16} \cdot \frac{T}{100} \cdot\left(\frac{2.35 \cdot 10^{19}}{N_{\mathrm{i}}}\right)^{1 / 3} .
$$


The electron mobility limited by dipole scattering was evaluated by the formula [15]

$$
\mu \approx \frac{8}{3} \cdot\left(\frac{\hbar}{k_{\mathrm{B}} T}\right) \cdot\left(\frac{e}{m^{*}}\right) \cdot\left(\frac{a_{0}}{d_{0}}\right)^{2} \cdot\left(\frac{N_{\mathrm{C}}}{N_{\mathrm{cl}}}\right),
$$

the density of dipoles $n_{0}$, dipole length $d_{0}$, the effective Bohr radius $a_{0}=4 \pi \varepsilon_{\mathrm{s}} / m^{*} e^{2}=30 \AA=0.53\left(\varepsilon_{\mathrm{r}} / m_{\mathrm{r}}\right) \AA$, where $m^{*}=m_{\mathrm{r}} m_{0}$ is the electron effective mass $\left(m_{0}\right.$ being the electron rest mass), static dielectric constant $\varepsilon_{\mathrm{s}}=\varepsilon_{\mathrm{r}} \varepsilon_{0}=11.9$.

The electron mobility limited by cluster scattering without the dipole feature was evaluated by the relation [16]

$$
1 / \mu=m^{*} / e v S_{\text {clus }},
$$

where $v$ is the thermal velocity of electron, the crosssection of cluster scattering $S_{\text {clus }}=10^{-11} \mathrm{~cm}^{2}$ and $N_{\text {clus }}$ is the cluster concentration. This term depends on temperature as $T^{-1}$. For the electron mobility limited by phonon scattering the data from [17] was used: $\mu=1 / a T^{2.42}$ and $\mu=1400 \mathrm{~cm}^{2 / \mathrm{vs} \text { at } 300} \mathrm{~K}$.

\section{Results}

The magnetoresistance mobility was investigated in the silicon samples irradiated by neutrons to $1 \cdot 10^{15}$ $1 \cdot 10^{17}$ neutron $/ \mathrm{cm}^{2}$ fluence at the Triga reactor (Ljubljana). The data was corrected to get the drift mobility values that were compared with a simulation which included all the above-presented scattering processes (Fig. 2). A choice of the contribution of different scattering processes started by fitting the mobility dependence on temperature that was very sensitive to contributions of different scattering processes, and the data corresponding to $300 \mathrm{~K}$ temperature was found and presented in Fig. 3. The following set of parameters was obtained:

1. The measured electron mobility in the nonirradiated sample with its value equal to $1200 \mathrm{~cm}^{2} /$ Vs that was lower than given in [16] could be caused by scattering on ionized impurities, because Si was compensated. The ionized impurity concentration was found by Eq. (3), and its value was found to be $8 \cdot 10^{14} \mathrm{~cm}^{-3}$.

2. As the interaction and transform of the defects were neglected, the proposed concentration of radiation-induced defects was proportional to the neutron fluence. As the neutron irradiation

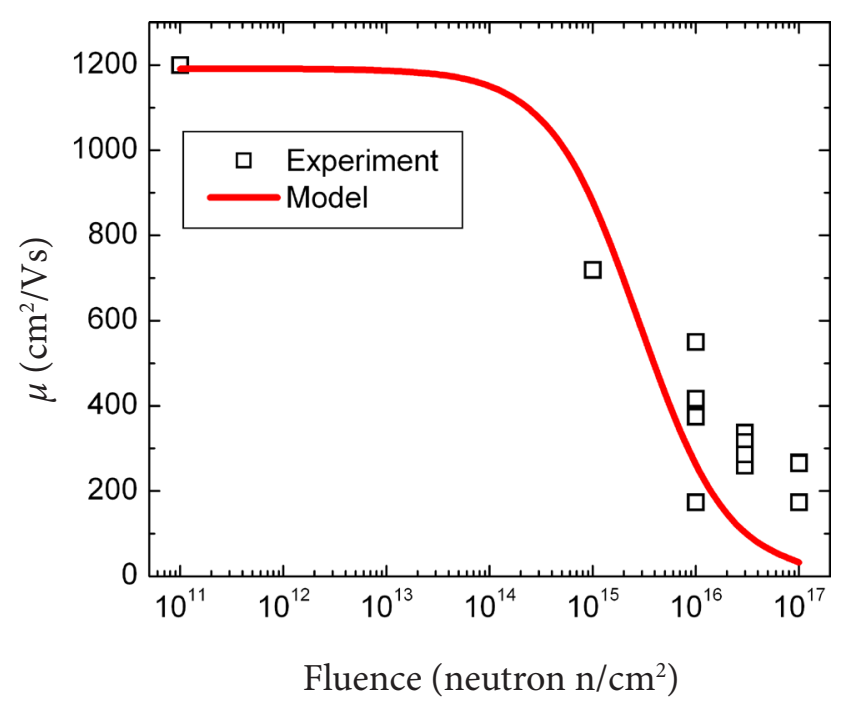

Fig. 2. The electron mobility measurement data (squares) and the result of simulation (solid line, red online) using the contribution of different scattering processes obtained by fitting of mobility temperature dependence shown in Fig. 3.

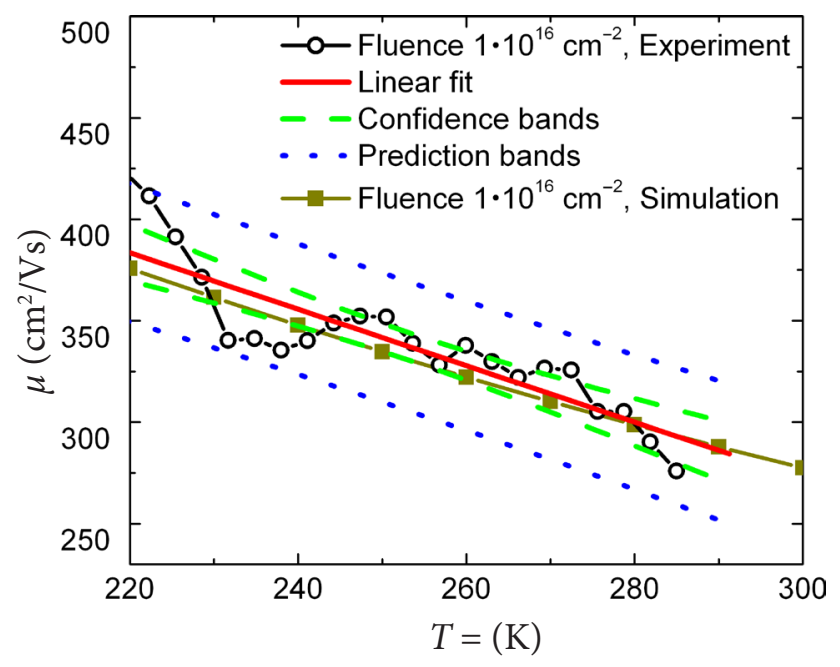

Fig. 3. The electron mobility dependence on temperature measurement data and a result of the best fit simulation using the dependence of different scattering processes on temperature (coloured online).

created mostly clusters [ [ $]$, it was proposed that at least $1 \%$ of neutrons created the ionized point defects.

3. The cross-section of cluster scattering was obtained equal to $S_{\text {clus }}=1.1 \cdot 10^{-15} \mathrm{~cm}^{2}$.

4. The proposal of proportionality to the neutron fluence resulted in only one third of clusters having dipole properties.

These results are illustrated in Table 1 . 
Table 1. The partial contribution in the dependence of electron mobility on the fluence by the defects.

\begin{tabular}{c|c|c|c|c|c}
\hline $\begin{array}{c}\text { Fluence, } \\
\mathrm{cm}^{-2}\end{array}$ & $\begin{array}{c}\text { Concentration } \\
\text { of point defects, } \\
\mathrm{cm}^{-3}\end{array}$ & $\begin{array}{c}\text { Mobility defined by } \\
\text { ionized point defects, } \\
\mathrm{cm}^{2} / \mathrm{Vs}\end{array}$ & $\begin{array}{c}\text { Mobility defined } \\
\text { by clusters, } \\
\mathrm{cm}^{2} / \mathrm{Vs}\end{array}$ & $\begin{array}{c}\text { Mobility defined } \\
\text { by dipoles, } \\
\mathrm{cm}^{2} / \mathrm{Vs}\end{array}$ & $\begin{array}{c}\text { Total mobility, } \\
\mathrm{cm}^{2} / \mathrm{Vs}\end{array}$ \\
\hline $1.00 \mathrm{E}+14$ & $8.01 \mathrm{E}+14$ & 7980 & 268323 & 38509 & 1150 \\
\hline $3.00 \mathrm{E}+14$ & $8.03 \mathrm{E}+14$ & 7979 & 89441 & 12836 & 1077 \\
\hline $6.00 \mathrm{E}+14$ & $8.06 \mathrm{E}+14$ & 7978 & 44721 & 6418 & 982 \\
\hline $1.00 \mathrm{E}+15$ & $8.10 \mathrm{E}+14$ & 7976 & 26832 & 3851 & 880 \\
\hline $3.00 \mathrm{E}+15$ & $8.30 \mathrm{E}+14$ & 7966 & 8944 & 1284 & 578 \\
\hline $5.00 \mathrm{E}+15$ & $8.50 \mathrm{E}+14$ & 7956 & 5366 & 770 & 430 \\
\hline $1.00 \mathrm{E}+16$ & $9.00 \mathrm{E}+14$ & 7933 & 2683 & 385 & 262 \\
\hline $3.00 \mathrm{E}+16$ & $1.10 \mathrm{E}+15$ & 7842 & 894 & 128 & 102 \\
\hline $1.00 \mathrm{E}+17$ & $1.80 \mathrm{E}+15$ & 7565 & 268 & 39 & 33 \\
\hline
\end{tabular}

\section{Discussion}

The good correspondence of data obtained in the analysis of the dependence of different scattering processes on temperature, simulation of mobility dependence on neutron fluence and the experimental data showed that at least up to neutron fluence of $10^{16} \mathrm{~cm}^{2}$ the defects did not interact. It was confirmed by the linear dependence of contribution of scattering by clusters and dipoles, which was dominating in defining the mobility value.

As proposed in [7], the dipoles could be the main recombination centres that provided the linear relation of fluence and lifetime [5]. The determined concentration of dipoles in the samples irradiated up to $1 \cdot 10^{16}$ neutrons $/ \mathrm{cm}^{3}$ permits evaluation of the free carrier recombination centre capture cross-section. As the lifetime follows the relation [18, 19,

$$
1 / \tau=v_{\text {thermal }} \sigma \mathrm{M}
$$

where $v_{\text {thermal }}$ is the electron thermal velocity, at $300 \mathrm{~K}$ equal to $10^{7} \mathrm{~cm} / \mathrm{s}$ [20], $\sigma$ is the capture of free carrier cross-section and $M$ is the concentration of recombination centres. Here and above we follow an approximation that 10 neutron $/ \mathrm{cm}^{2} \mathrm{flu}-$ ence creates 10 cluster $/ \mathrm{cm}^{3}$ [1] $]$. The experiment of slow neutron scattering obtained 2.5 times greater value [3]. The lifetime in Si irradiated to $10^{16}$ neutron $/ \mathrm{cm}^{2}$ fluence is equal to $0.42 \mathrm{~ns}$ [21], the concentration of recombination centres, i.e. dipoles, $M=3.3 \cdot 10^{15} \mathrm{~cm}^{-3}$, then the capture of free carrier cross-section is equal to $\sigma=7.210^{-14} \mathrm{~cm}$. It could be recognized being as a weak attractive centre.
The analysis of experimental data clearly shows that the applied model did not explain the mobility in the samples irradiated to the highest fluence. Therefore a new concept of carrier transport is needed. The measurement data was approximated by polynomial regression that is shown in Fig. 4 , and the approximation was statistically correct $(p=0.0048)$.

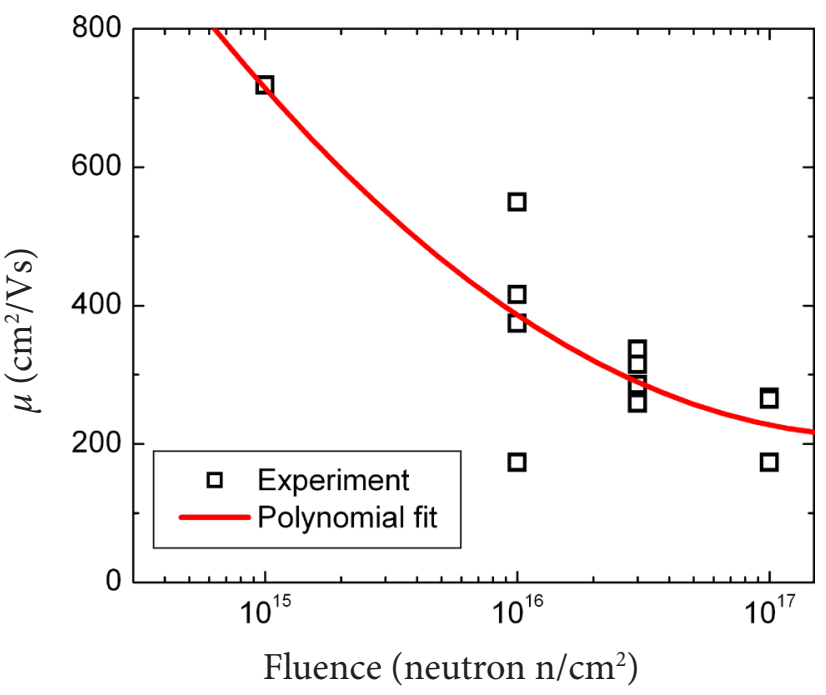

Fig. 4. The measurement data (squares) and approximation (solid line, red online) by polynomial regression.

The approximation curve demonstrated a tendency to change the $\mathrm{Si}$ conductivity nature. The Mott density [22] for excitons obtained $n_{\text {Mott }}=$ $3.6 \cdot 10^{17} \mathrm{~cm}^{-3}$ that could be comparable for our case if a random distribution of the clusters is taken into account. As a conclusion could be the statement that $\mathrm{Si}$ irradiated above $10^{16} \mathrm{~cm}^{-2}$ 
fluence (and up to $10^{20} \mathrm{~cm}^{-2}[3]$ ) is a disordered material with the clusters.

\section{Acknowledgements}

This work, performed in the framework of the CERN-RD50 collaboration, has been funded by the Lithuanian Academy of Sciences for the Project CERN-RD50.

We are also grateful to AIDA Transnational Access for irradiations in the Triga reactor (Ljubljana).

\section{References}

[1] M. Huhtinen, Simulation of non-ionising energy loss and defect formation in silicon, Nucl. Instrum. Methods A 491, 194-215 (2002), https://doi.org/10.1016/S0168-9002(02)01227-5

[2] I. Pintilie, G. Lindstroem, A. Junkes, and E. Fretwurst, Radiation-induced point- and cluster-related defects with strong impact on damage properties of silicon detectors, Nucl. Instrum. Methods 611, 52-68 (2009), https://doi.org/10.1016/j. nima.2009.09.065

[3] R.E. Beddoe, S. Messoloras, R.J. Stewart, G. Kostorz, and E.W.J. Mitchell, Temperature-dependent neutron scattering from silicon single crystals, Philos. Mag. A 48, 935-952 (1983), https://doi. org/10.1080/01418618308244328

[4] I. Mandić, V.Cindro, A. Gorišek, B. Hiti, G. Kramberger, M. Mikuž, M. Zavrtanik, P. Skomina, S. Hidalgo, and G. Pellegrini, Measurements with silicon detectors at extreme neutron fluences, JINST 15, P11018 (2020), https://doi. org/10.1088/1748-0221/15/11/p11018

[5] E. Gaubas, T. Čeponis, L. Deveikis, D. Meškauskaite, J. Pavlov, V. Rumbauskas, J. Vaitkus, M. Moll, and F. Ravotti, Anneal induced transformations of defects in hadron irradiated Si wafers and Schottky diodes, Mater. Sci. Semiconduct. Process. 75, 157-165 (2018), https://doi. org/10.1016/j.mssp.2017.11.035

[6] E. Žąsinas and J. Vaitkus, Disordered small defect cluster in silicon, Lith. J. Phys. 55, 330-334 (2015), https://doi.org/10.3952/physics.v55i4.3231

[7] E. Žąsinas and J. Vaitkus, Modelling of Radiation Induced Vacancy-Interstitial Clusters, in: Book of
Abstracts, 26thRD50Workshop(2015)p.9,https:// indico.cern.ch/event/381195/book-of-abstracts. pdf; https://indico.cern.ch/event/381195/contributions/905641/attachments/759529/1041866 Vaitkus-RD50-Zasinas_2.pdf

[8] J. Ziegler, SRIM \& TRIM, http://www.srim.org/

[9] R. Radu, I. Pintilie, L.C. Nistor, E. Fretwurst, G. Lindstroem, and L.F. Makarenko, Investigation of point and extended defects in electron irradiated silicon - Dependence on the particle energy, J. Appl. Phys. 117, 164503 (2015), https://doi. org/10.1063/1.4918924

[10]T.J. Brodbeck, A. Chilingarov, T. Sloan, E. Fretwurst, M. Kuhnke, and G. Lindstroem, Carrier mobilities in irradiated silicon, Nucl. Instrum. Methods A 477, 287-292 (2002), https://doi. org/10.1016/S0168-9002(01)01858-7

[11]J.V. Vaitkus, A. Mekys, V. Rumbauskas, and J. Storasta, Neutron irradiation influence on mobility and compensation of dark conductivity in silicon, Lith. J. Phys. 56, 102-110 (2016), https://doi. org/10.3952/physics.v56i2.3306

[12]D.K. Schröder, Semiconductor Material and Device Characterization (A. Wiley-Interscience Publication, N. Y., 1990).

[13]L. Donetti, F. Gamiz, and S. Cristoloveanu, Monte Carlo simulation of Hall and magnetoresistance mobility in SOI devices, Solid State Electron. 51, 1216-1220 (2007), https://doi.org/10.1016/j. sse.2007.07.022

[14]E.M. Conwell and V.F. Weisskopf, Theory of impurity scattering in semiconductors, Phys. Rev. 77, 388-390 (1950), https://doi.org/10.1103/ PhysRev.77.388

[15]R. Stratton, Dipole scattering from ion pairs in compensated semiconductors, J. Phys. Chem. Solids 23, 1011 (1962), https://doi. org/10.1016/0022-3697(62)90159-2

[16]K.W. Böer, Handbook of the Physics of Thin-Film Solar Cells (Springer Science \& Business Media, Berlin, 2014).

[17]C. Jacoboni, C. Canali, G. Ottaviani, and A. Albrigi Quaranta, A review of some charge transport properties of silicon, Solid State Electron. 20, 77-89 (1977), https://doi.org/10.1016/00381101(77)90054-5 
[18]A. Rose, Concepts in Photoconductivity and Allied Problems (Interscience Publishers, 1963).

[19]J.S. Blakemore, Semiconductor Statistics (Elsevier, 2016).

[20]B. Van Zeghbroeck, Principles of Semiconductor Devices (University of Colorado, 2007).

[21]S. Olibet, E. Vallat-Sauvain, and Ch. Ballif, Model for a-Si:H/c-Si interface recombination based on the amphoteric nature of silicon dangling bonds, Phys. Rev. B 76, 1-14 (2007), https://doi. org/10.1103/PhysRevB.76.035326

[22] G.B. Norris and K.K. Bajaj, Exciton-plasma mott transition in Si, Phys. Rev. B 26, 6706-6710 (1982), https://doi.org/10.1103/PhysRevB.26.6706

\title{
STIPRIAI APŠVITINTO NEUTRONAIS SILICIO ELEKTRONŲ JUDRIO PRIKLAUSOMYBĖ NUO NEUTRONŲ İTÉKIO
}

\author{
J.V. Vaitkus, A. Mekys, Š. Vaitekonis \\ Vilniaus universiteto Fotonikos ir nanotechnologiju institutas, Vilnius, Lietuva
}

\section{Santrauka}

Didinant greitųjų neutronų ittèkį, krinta Si radiacinių detektorių naudingumas. Tai aiškiausiai matosi įtėki padidinus iki $10^{17} \mathrm{n} / \mathrm{cm}^{2}$, kai p-n jungties voltamperinè charakteristika tiesiogine ir priešinga kryptimis susivienodina. Tokios medžiagos laisvųjų krūvininkų judrio tyrimai galètų atskleisti apšvitinto Si savybių pasikeitimus.

Darbe krūvininkų judris buvo nustatomas iš magnetovaržos reiškinio mikrostripelių pavidalo Si bandiniuose $T=200-276 \mathrm{~K}$ temperatūros intervale. Pernašos reiškiniams analizuoti buvo įskaitoma laisvųjų krūvininkų sklaida fononais, jonizuotomis priemaišomis, dipoliais ir defektų klasteriais. Kiekvieno iš ju indèlis buvo nustatomas atskirai pritaikant judrio temperatūriniam kitimui matematines išraiškas.

Eksperimentinių duomenų analizè aiškiai parodè, kad didžiausio paminèto ittèkio bandiniuose naudojamas pernašos modelis netinka judrio temperatūriniam dèsningumui paaiškinti. Reikalingas naujas modelis šiems pernašos reiškiniams aiškinti, o iš gautų rezultatų galima daryti išvadą, kad Si švitintas įtèkiu per $10^{16} \mathrm{~cm}^{-2}$ (ir iki $10^{20} \mathrm{~cm}^{-2}$ ) yra netvarki medžiaga su defektiniais klasteriais. 